\title{
Anticancer Effects of Combined $\gamma$-Tocotrienol and PPAR $\gamma$ Antagonist Treatment are Associated with a Suppression in Adipogenic Factor Expression
}

\author{
Abhita Malaviya, Parash Parajuli and Paul W. Sylvester \\ College of Pharmacy, University of Louisiana at Monroe, Monroe, Louisiana 71209, USA
}

\begin{abstract}
Cancer cells reprogram their metabolism to meet the demands of accelerated growth. Glucose is the primary source of energy for cancer cells, but under conditions of high-energy demand lipids and free fatty acids become increasingly important. PPAR $\gamma$ is a member of the nuclear receptor superfamily and acts to regulate adipocyte differentiation and lipid metabolism. However, in many types of cancer, PPAR $\gamma$ activity is elevated in order to increase production of adipogenic factors [1, 2]. $\gamma$-Tocotrienol is an isoform of vitamin $E$ that displays potent anticancer activity [3]. Previous studies have shown that the antiproliferative effects of combined treatment of $\gamma$-tocotrienol with PPAR antagonists was associated with a reduction in PPAR $\gamma$ activity, expression of PPAR $\gamma$ and RXR, and suppression in Akt activation in MCF-7 and MBA-MB-231 human breast cancer cells [4]. The present study was conducted to determine the effects of combination treatment with these agents on adipogenic factor levels in rapidly proliferating human breast cancer cells. Western blot and qRT-PCR studies showed that combined treatment of $\gamma$-tocotrienol with PPAR $\gamma$ antagonists not only suppressed the adipogenic proteins, C/EBP $\beta$ and SREBP-1c, but also decreased their target lipogenic enzymes, ap2, FAS, and HMGCoR. However, treatment effects were also observed in PPAR $\gamma$ silenced breast cancer cells, indicating that these effects are mediated through PPAR $\gamma$-independent mechanism. These findings suggest the combined treatment of $\gamma$-tocotrienol with PPAR $\gamma$ antagonist may have potential as a therapeutic strategy in the treatment of breast cancer.
\end{abstract}

Keywords: $\gamma$-Tocotrienol, PPAR $\gamma$, Breast Cancer, C/EBP $\beta$, SREBP-1c, FASN.

\section{INTRODUCTION}

Cancer cells characteristically display an elevated metabolism and consume vast amounts of energy to support their growth and survival. Although, glucose is the primary energy source for cancer cells, during conditions of high-energy demand, lipids and free fatty acids can replace glucose as an important energy source. Adipocytes modulate lipid metabolism and are also involved in activating signaling pathways associated with promoting chronic inflammation [5]. Although it has not yet been firmly established that lipids derived from insulin-resistant adipocytes have a direct impact on cancer cell metabolism, evidence does suggest that activation of adipocytes appears to be involved in supporting growth and proliferation in malignant cells [5]. Peroxisome proliferator activated receptor $\gamma$ (PPAR $\gamma$ ), a member of the nuclear receptor superfamily, is expressed predominantly in adipose tissue, where it functions to regulates adipocyte differentiation and lipid metabolism [6]. Studies have shown that PPAR $\gamma$ levels are elevated in many types of cancer tissues $[1,7,8]$. PPAR $\gamma$ may function in cancer cells to increase production of adipogenic factors and lipogenic proteins in support of the high metabolic demands of cancer cells [2, 9]. Therefore, strategies

*Address correspondence to this author at the College of Pharmacy, 700 University Avenue, University of Louisiana at Monroe, Monroe, LA 71209, USA; Tel: +1 3183421958; Fax: +1 3183421737; E-mail: sylvester@ulm.edu targeting the inhibition of PPAR $\gamma$ may be beneficial in the treatment of cancer by acting to decrease adipogenic proteins and genes in rapidly proliferating cancer cells.

PPAR $\gamma$ regulates adipogenesis by activating families of transcription factors such as CCAATenhancer-binding proteins (C/EBP) and sterol regulatory element binding protein (SREBP; also called ADD1) $[10,11]$. Studies have shown that of the three isoforms of $\mathrm{C} / \mathrm{EBP}$ (C/EBPa, C/EBP $\beta$, and C/EBPD), PPAR $\gamma$ directly regulates $\mathrm{C} / \mathrm{EBP} \alpha$ and $\mathrm{C} / \mathrm{EBP} \beta$ to maintain a terminally differentiated state of adipocytes that is absolutely required for the function of fatselective enhancers such as adipocyte fatty acid binding protein (also called ap2) [12, 13]. In addition, PPAR $\gamma$ regulates function of SREBP-1c and SREBP2, which are important regulators of fatty acid uptake and enhance fatty acid (FA) synthesis by modulating activity of key lipogenic enzymes such as FA synthase (FASN) and 3-hydroxy-3-methyl-glutaryl-CoA reductase (HMGCoR) [14-16]. Investigations have also shown that specific C/EBP and SREBP isoforms are over expressed in many types of cancers in order to compensate for the elevated energy demand displayed by these cells $[17,18]$.

$\gamma$-Tocotrienol is a naturally occurring isoform within the vitamin E family of compounds that displays potent 
anticancer activity $[19,20]$ by suppression of growthfactor-dependent mitogenic signaling [21, 22]. In vitro studies have previously shown that mammary tumor cells exposed to $\gamma$-tocotrienol treatment display a significant reduction in 3-hydroxy-3-methylglutaryl-CoA reductase activity through posttranscriptional downregulation of this enzyme [23]. Additional studies showed that $\gamma$-tocotrienol inhibits adipogenesis in 3T3L1 preadipocytes by suppressing insulin-induced ap2 protein and Akt phosphorylation [24], and reduce SREBP expression in human fibroblasts [25].

The antiproliferative effects of $\gamma$-tocotrienol may be due to changes in PPAR $\gamma$ activity [26], Studies conducted in human breast cancer cells showed that the antiproliferative effects resulting from combined treatment of $\gamma$-tocotrienol with PPAR $\gamma$ antagonists (GW9662 or T0070907) was associated with a reduction in PPAR $\gamma$ expression and activity [4]. However, the effects of these combination treatments on lipogenic enzymes have not yet been determined. Therefore, studies were conducted to determine the effects of combination treatment of $\gamma$-tocotrienol with PPAR $\gamma$ antagonists on C/EBP and SREBP isoforms and their target lipogenic genes. In addition, experiments were conducted to understand whether these effects are mediated by PPAR $\gamma$-dependent versus PPAR $\gamma$-independent mechanisms.

\section{MATERIALS AND METHODS}

\subsection{Reagents and Antibodies}

Unless stated otherwise, all reagents were purchased from Sigma Chemical Company (St. Louis, MO). Isolated $\gamma$-tocotrienol ( $>98 \%$ purity) used in experimentation was acquired from First Tech International Ltd (Hong Kong). The PPAR $\gamma$ antagonists, GW9662 and T0070907, were purchased from Cayman Chemicals (San Diego, CA). Cells grown in culture were maintained in media that contain fetal bovine serum (FBS) that was purchased from American Type Culture Collection (Manassas, VA). Primary antibodies used in Western blot analysis for $\beta$ actin, PPAR $\gamma, \mathrm{C} / \mathrm{EBPa}, \mathrm{C} / \mathrm{EBP} \beta$, lipin 1, FASN, ap2, and HMGCoR were purchased from Cell Signaling Technology (Beverly, MA), while the primary antibody directed against SREBP-1c was purchased from Santa Cruz Biotechnology (Santa Cruz, CA). Secondary antibody used in Western blot analysis was goat antirabbit and was purchased from PerkinElmer Biosciences (Boston, MA).

\subsection{Cell Lines and Culture Conditions}

The human breast cancer cell lines, MCF-7 and MDA-MB-231, used in experimentation were purchased from American Type Culture Collection (Manassas, VA). MCF-7 is an estrogen-receptorpositive, whereas MDA-MB-231 is an estrogenreceptor negative, ductal epithelial cancer breast cell. Both breast cancer cell lines were maintained in a 1:1 mixture of modified Dulbecco's modified Eagle's medium (DMEM) and Ham's F12 medium supplemented with $10 \%$ fetal bovine serum, $10 \mu \mathrm{g} / \mathrm{ml}$ insulin, $100 \mathrm{U} / \mathrm{ml}$ penicillin, $0.1 \mathrm{mg} / \mathrm{ml}$ streptomycin. Cells were maintained in a humidified incubator at $37^{\circ} \mathrm{C}$ in a $95 \%$ air and $5 \% \mathrm{CO}_{2}$ environment. Prior to experimentation, cells were harvested for subculturing, media was removed and cells were twice washed with sterile $\mathrm{Ca}^{2+}$ - and $\mathrm{Mg}^{2+}$ - free phosphate-buffered saline (PBS). Cells were then incubated in $0.05 \%$ trypsin containing $0.025 \%$ EDTA in PBS for $5 \mathrm{~min}$ at $37^{\circ} \mathrm{C}$. Afterward, the now released cells were collected by centrifugation, and then resuspended in serum containing media. The number of harvested cells was then calculated using a hemocytometer as previously described in detail [19].

\subsection{Experimental Treatments}

All isoforms of vitamin $E$ are highly lipophilic. Therefore, in order to dissolve $\gamma$-tocotrienol into the aqueous culture media, it must first be suspended in a sterile $10 \%$ bovine serum albumin (BSA) solution [19, 20]. This is accomplished by first taking a known amount of purified $\gamma$-tocotrienol and dissolving it in 100 $\mu \mathrm{L}$ of $100 \%$ ethanol. Once dissolved, this $\gamma$ tocotrienol/ethanol solution is then added to a small volume of sterile $10 \%$ BSA in water to produce a final $10 \mathrm{mM} \gamma$-tocotrienol/BSA stock solution. This stock solution is then incubated overnight at $37^{\circ} \mathrm{C}$ with continuous shaking. From this stock solution, different concentration of $\gamma$-tocotrienol containing treatment media is prepared. Likewise, stock solutions of the highly lipophilic PPAR $\gamma$ antagonist, GW9662 and T0070907, were prepared by dissolving these agents in sterile dimethyl sulfoxide (DMSO), and then the appropriate amount of this stock solution was then added directly to treatment media. Ethanol and/or DMSO can induce toxic effects to cells in culture if concentrations reach levels greater than $1 \%$. Therefore, as a treatment control, the levels ethanol and/or DMSO were adjusted in all control and treatment media so that exposure to these agents was the same for all cells in a particular experiment. The 
final concentration of ethanol and/or DMSO within any given experiment was always less than $0.1 \%$.

\subsection{Growth Studies}

In dose-response studies examining the antiproliferative effects of the various treatments, MCF7 and MDA-MB-231 breast cancer cells were isolated, resuspended and counted as described above in section 2.2. Cells were then seeded at a density of $1 \times 10^{4}$ cells suspended in $100 \mu \mathrm{L}$ control media into each well of a 96-well culture plate, returned to the incubator and allowed to adhere to the bottom of the plate. The next day, cells were divided into different treatment groups and the original media was removed. Cells were then washed with $100 \mu \mathrm{L}$ of sterile PBS and then all wells received $100 \mu \mathrm{L}$ of their respective treatment media containing either 0-12 $\mu \mathrm{M}$ GW9662, T0070907 or 0-6 $\mu \mathrm{M} \gamma$-tocotrienol alone or combination and then plates were returned to the incubator. Treatment media was replaced with fresh media every other day throughout the 4-day experimental period.

\subsection{Measurement of Viable Cell Number}

MCF-7 and MDA-MB-231 breast cancer cell number was determined in 96-well culture plates (8 wells/group) by the 3-(4, 5-dimethylthiazol-2yl)-2, 5diphenyl tetrazolium bromide (MTT) colorimetric assay using a modification of the method previously described in detail $[19,20]$. On the day of assay, treatment medium was replaced with fresh control medium containing $0.5 \mathrm{mg} / \mathrm{mL}$ MTT, and cells were returned to the incubator for $3 \mathrm{~h}$. At the end of the incubation period, treatment media was removed, and the MTT crystals were dissolved in $100 \mu \mathrm{L}$ of DMSO. The optical density of each sample was read at $570 \mathrm{~nm}$ on a microplate reader (Spectracount; Packard Bioscience Company, Meriden, CT) that was zeroed against a blank prepared from cell-free cultures. The number of cells/well was calculated against a standard curve prepared by plating various concentrations of cells, as determined by hemocytometer, in triplicate at the start of each experiment. Previous studies showed that $\gamma$-tocotrienol treatment does not affect the specific activity of the MTT assay $[19,20]$.

\subsection{Western Blot Analysis}

In studies measuring treatment effects on PPAR $\gamma$ signaling protein or lipogenic factor expression by Western blot analysis, $1 \times 10^{6}$ MCF-7 or MDA-MB-231 breast cancer cells were resuspended in $10 \mathrm{~mL}$ of control medium and plated in $100 \mathrm{~mm}$ culture plates. Plates were then returned to the incubator to allowed cells to attach to the bottom of the plate. The next day, media was removed and the cells were washed with 10 $\mathrm{mL}$ sterile PBS, divided into the various treatment groups and fed $10 \mathrm{~mL}$ of their respective treatment media. Cells were then returned to the incubator. Fresh media was replaced every other day for the remainder of the 4-day experimental period. Afterwards, cells were twice washed with sterile PBS, and isolated with trypsin as described above. Whole cell lysates were prepared by resuspending cells in lysis buffer, then boiled for $5 \mathrm{~min}$, sonicated, microcentrifuged at $4^{\circ} \mathrm{C}$ and the supernatant was collected [22, 27, 28]. The protein concentration in each sample was determined using a Bio-Rad protein assay kit (Bio-Rad, Hercules, CA). Equal amounts of protein from each sample in a given experiment was then loaded onto SDSpolyacrylamide minigels and electrophoresed through a $15 \%$ resolving gel. Separated proteins on each gel were then transferred to a polyvinylidene fluoride (PVDF) membrane at $30 \mathrm{~V}$ for $12-16 \mathrm{~h}$ at $4^{\circ} \mathrm{C}$ (PerkinElmer Lifesciences, Wellesley, MA) in a TransBlot Cell (Bio-Rad, Hercules, CA) according to the method of Towbin et al. [29]. Nonspecific antibody binding sites were blocked on each transblotted membranes by incubating membranes in 2\% BSA in 10 $\mathrm{mM}$ Tris $\mathrm{HCl}$ containing $50 \mathrm{mM} \mathrm{NaCl}$ and $0.1 \%$ Tween $20 \mathrm{pH} 7.4$ (TBST) for $2 \mathrm{~h}$, followed by an incubation with specific primary antibodies against PPAR $\gamma$, C/EBPa, C/EBP $\beta$, SREBP-1c, lipin 1, FASN, ap2, HMGCoR or $\beta$-actin, diluted $1: 500$ to $1: 5000$ in TBST $/ 2 \%$ BSA for $2 \mathrm{~h}$. Afterwards, membranes are washed 5 times with TBST followed by incubation with their respective horseradish peroxide-conjugated secondary antibodies diluted $1: 3000$ to $1: 5000$ in TBST $/ 2 \%$ BSA for $1 \mathrm{~h}$, and then washed again with TBST. Specific target protein bands on each membrane were then visualized by chemiluminescence (Pierce, Rockford, IL) according to the manufacturer's instructions. Images were obtained using a Syngene Imaging System (Frederick, MD). The visualization of $\beta$-actin in each sample was used as a control standard to verify the equal sample loading occurred in each lane. Protein bands images were then acquired and densitometric analysis was performed with the Kodak molecular imaging software version 4.5 (Carestream Health Inc, Rochester, NY). All experiments were repeated at least three times. Representative Western blot images from each experiment are shown in the Figures.

\subsection{Transient Transfection and Luciferase Reporter Assay}

In transfection and reporter assays, $2 \times 10^{4} \mathrm{MCF}-7$ or MDA-MB-231 breast cancer cells were resuspended in 
$100 \mu \mathrm{L}$ of control medium and plated in each well of a 96-well culture plate. Plates were then returned to the incubator to allow cells to attach to the bottom of the plate. The next day, media was replaced with fresh control media. Cells in each well were then transfected with $32 \mathrm{ng}$ of PPRE X3-TK-luc (Addgene plasmid \#1015) (Kim et al., 1998) and $3.2 \mathrm{ng}$ of renilla luciferase plasmid per well (Promega, Madison, WI) using $0.8 \mu \mathrm{L}$ of lipofectamine ${ }^{\mathrm{TM}} 2000$ transfection reagent (Invitrogen, Grand Island, NY) and returned to the incubator. Following a $6 \mathrm{~h}$ incubation period, the transfection media was removed, cells were washed in $100 \mu \mathrm{L}$ sterile PBS, and then exposed to $100 \mu \mathrm{L}$ of control or treatment media and returned to the incubator, and fresh media was provided every other day. After a 4-day experimental period, cells were lysed with $75 \mu \mathrm{L}$ of passive lysis buffer and treated according to manufacturer's instructions using dual-glo luciferase assay system (Promega, Madison, WI). Renilla activity in each sample was used to normalize luciferase activity. Experimental results are represented as the mean-fold change in activity observed in treated cells, as compared to the activity observed in vehicle-treated control cells.

\subsection{Quantitative Real-Time PCR}

In qPCR studies, $2 \times 10^{5}$ MCF-7 or MDA-MB-231 breast cancer cells were resuspended in $2 \mathrm{~mL}$ of control medium and plated in each well of a 6-well culture plate and then returned to the incubator to allowed cells to attach to the bottom of the plate. The next day, cells were divided into different treatment groups (3 wells/group) culture media was removed, washed with sterile PBS, then fed fresh media containing their respective treatments that included 0 -

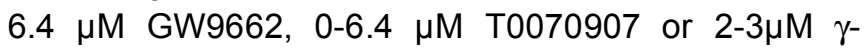
tocotrienol alone or in combination and then return to the incubator. Cells were fed fresh media every other day during the 4-day culture period. Total RNA was extracted using Applied Biosystems (Carlsbad, CA) RNA kit according to the manufacturer's instructions. First-strand cDNA was generated from total RNA for each sample using the cDNA kit from Applied Biosystems (Carlsbad, CA) according to the manufacturer's instructions. Taqman PCR probes and gene-specific primer pairs were generated for PPAR $\gamma$, RXR, C/EBP $\beta$, SREBP-1c, and GAPDH using Integrated DNA technologies (Coralville, IA). qRT-PCR was performed on an Applied Biosystems (Carlsbad, CA) Prism 7900 Sequence Detection System. Reactions were prepared in triplicate for each gene using Taqman gene expression assays. During thermal cycling, the threshold cycle $\left(C_{t}\right)$ is defined as the cycle number when amplification of a specific PCR product is detected. The average $C_{t}$ value of GAPDH was subtracted from average $C_{t}$ value of target genes (PPAR $\gamma, R X R, C / E B P \beta$, SREBP-1c) to normalize the amount of sample RNA added to the reaction. Relative quantification describes the fold change in expression of a gene of interest in a test sample relative to a calibrator sample. With the comparative $\mathrm{C}_{t}\left(\Delta \Delta \mathrm{C}_{t}\right)$ method, the level of the target gene mRNA in treatment samples relative to control samples was determined.

\subsection{Statistical Analysis}

Differences among the various treatment groups in growth studies and Western blot studies were determined by analysis of variance followed by Dunnett's multiple range test. Differences were considered statistically significant at a value of $P<0.05$.

\section{RESULTS}

\subsection{Antiproliferative Effects of $\gamma$-Tocotrienol and PPAR $\gamma$ Antagonists (GW9662 or T0070907) when Given Alone and in Combination}

Treatment with 3-4 $\mu \mathrm{M} \gamma$-tocotrienol, or 3.2-6.4 $\mu \mathrm{M}$ GW9662 or T0070907 was found to significantly inhibit growth of MCF-7 cells in a dose-responsive manner as compared to cells in the vehicle treated control group (Figure 1A and B). However, when combined with a subeffective dose $(3.2 \mu \mathrm{M})$ of the PPAR $\gamma$ antagonist, GW9662 and T0070907, the growth inhibitory effects of 1-4 $\mu \mathrm{M} \gamma$-tocotrienol was significantly enhanced in MCF-7 breast cancer cells (Figure 1C and D). Similarly, treatment with 4-6 $\mu \mathrm{M} \gamma$-tocotrienol, or 6.4-12 $\mu \mathrm{M}$ GW9662 or T0070907 was found to significantly inhibit growth of MDA-MB-231 cells in a dose-responsive manner as compared to cells in the vehicle treated control group (Figure 1E and F). However, the growth inhibitory effects of 3-6 $\mu \mathrm{M} \quad \gamma$-tocotrienol was significantly enhanced when given in combination with a subeffective dose $(6.4 \mu \mathrm{M})$ of the PPAR $\gamma$ antagonists, GW9662 and T0070907, in MDA-MB-231 breast cancer cells (Figure 1G and $\mathbf{H}$ ).

3.2. Effects of $\gamma$-Tocotrienol and PPAR $\gamma$ Antagonists (GW9662 or T0070907) Given Alone or in Combination on PPAR $\gamma$ and RXR mRNA Levels and PPRE Mediated Reporter Activity

qRT-PCR analysis shows that treatment with $2 \mu \mathrm{M}$ (MCF-7 cells) or $3 \mu \mathrm{M}$ (MDA-MB-231 cells) $\gamma$ tocotrienol alone did not affect PPAR $\gamma$ and RXR mRNA 
MCF-7

A)

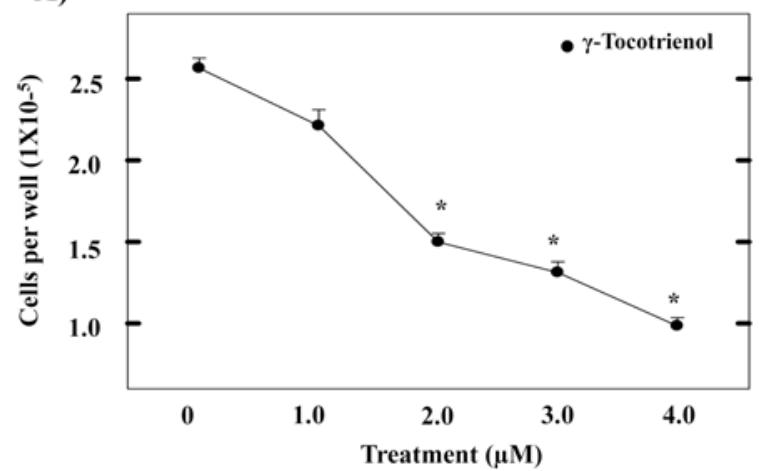

B)

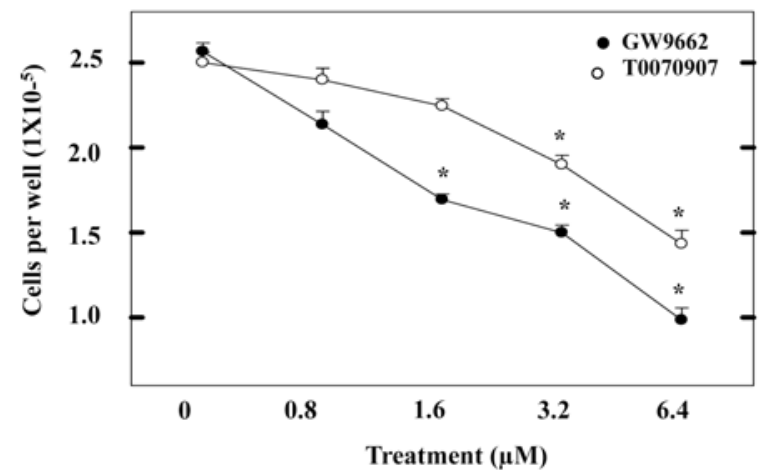

C)

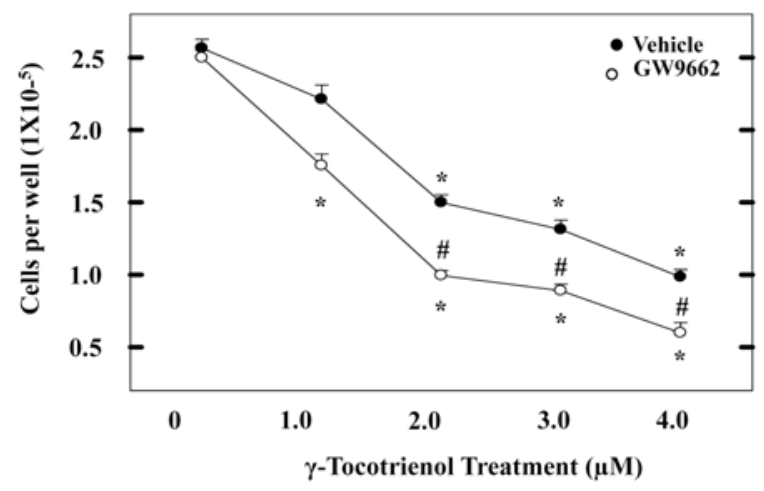

D)

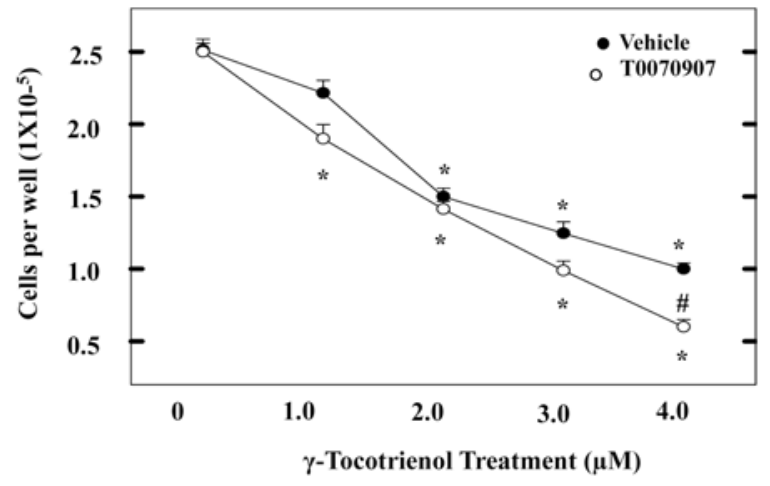

MDA-MB-231

E)

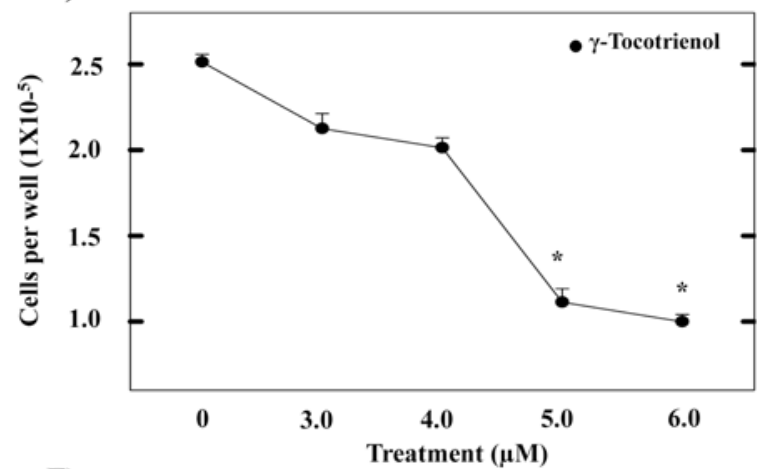

F)

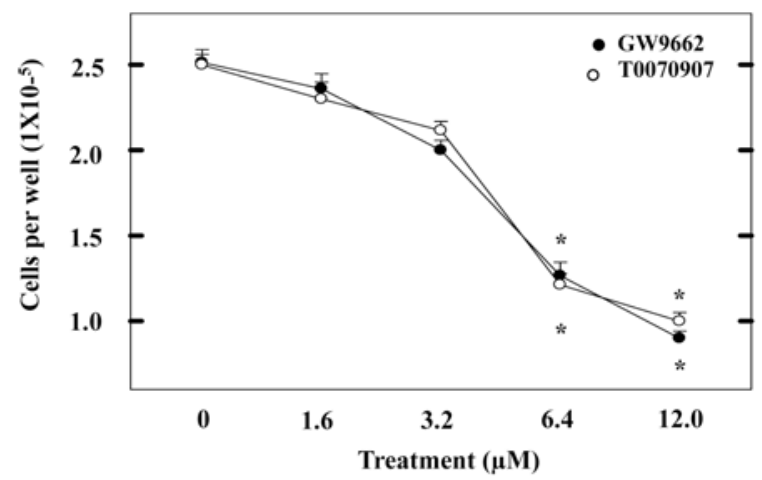

G)

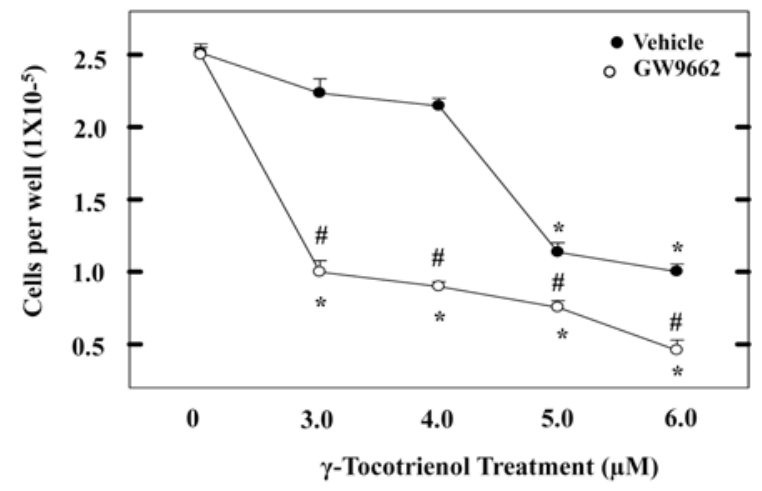

H)

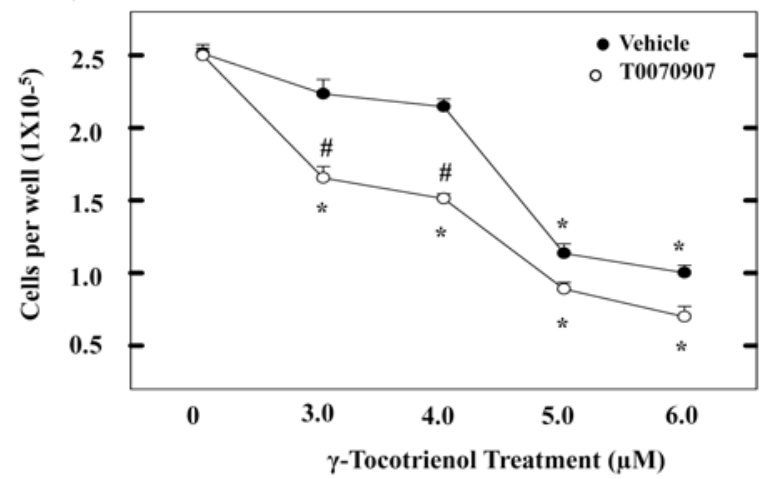

Figure 1: Antiproliferative effects of $\gamma$-tocotrienol and PPAR $\gamma$ antagonists (GW9662 and T0070907) on (A, B, C, D) MCF-7 and $(\mathbf{E}, \mathbf{F}, \mathbf{G}, \mathbf{H})$ MDA-MB-231 breast cancer cells. Cells were plated at a density of $1 \times 10^{4}$ cells/well in 96 -well culture plate $(3$ replicates per group) and exposed to treatment media for a 4-day period. Afterwards viable cell number was determined using MTT colorimetric assay. Vertical bars indicate mean cell count \pm SEM in each treatment group. ${ }^{*} \mathrm{P}<0.05$ as compared with vehicle-treated controls. 
MCF-7

A)

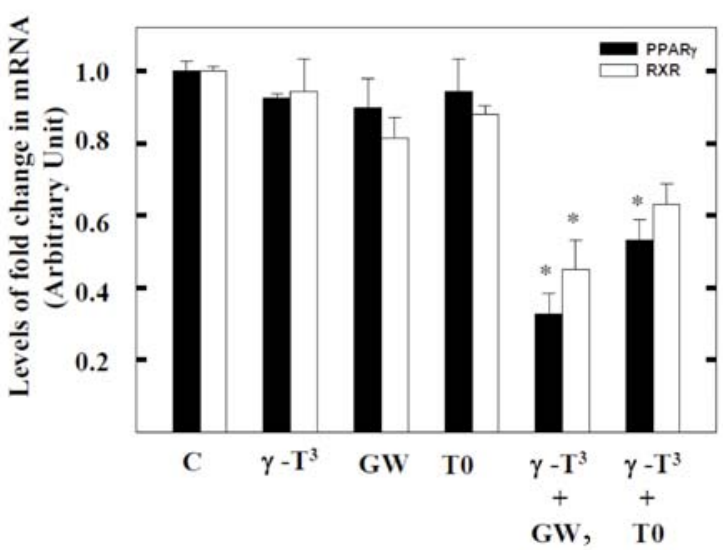

C)

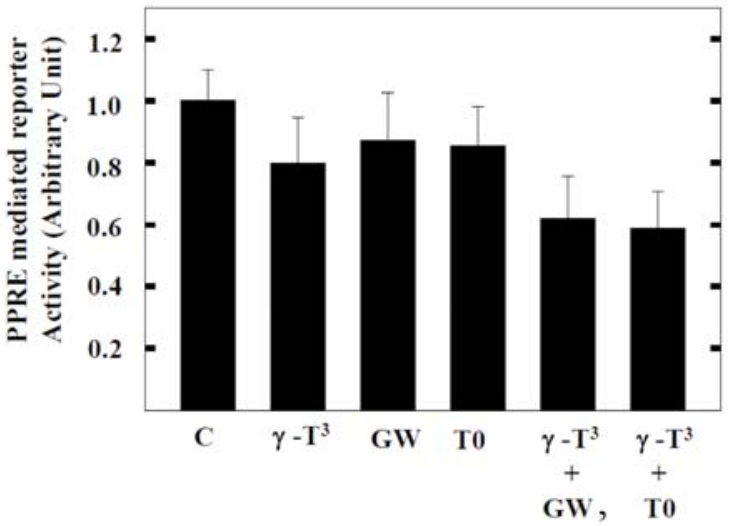

C-Control; $\gamma-\mathrm{T}^{3}-2 \mu \mathrm{M} \gamma$-Tocotrienol; GW-3.2 $\mu \mathrm{M}$ GW9662; T0 - 3.2uM T0070907
B

MDA-MB-231

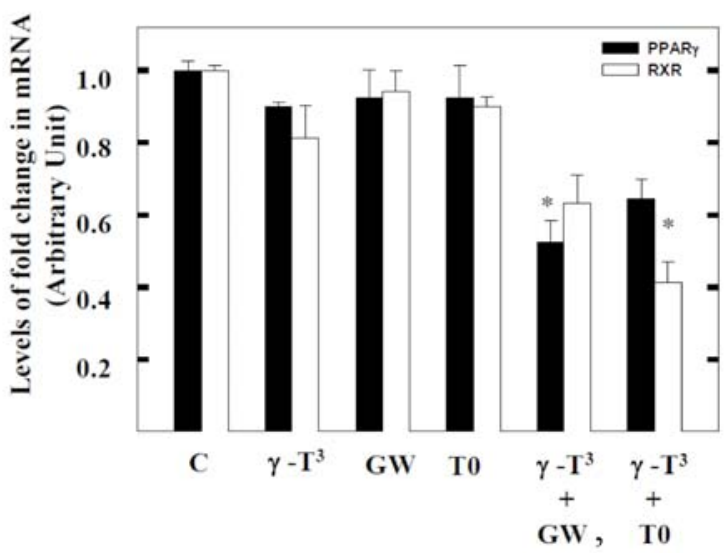

D)

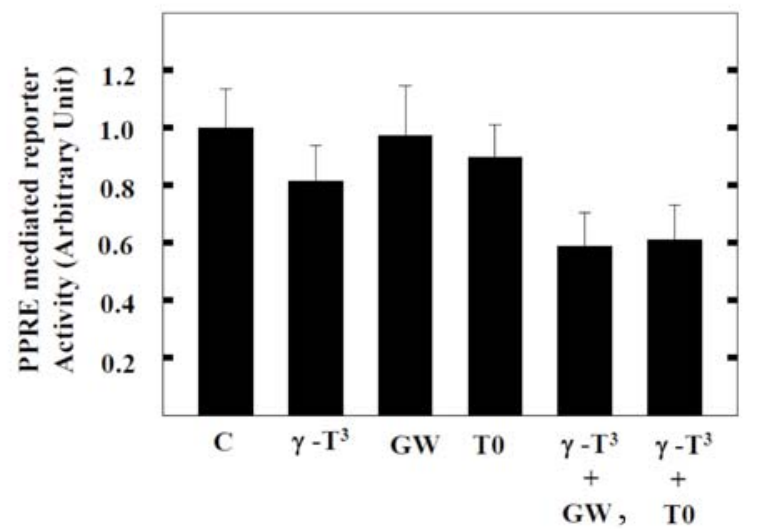

C-Control; $\gamma-T^{3}-3 \mu M \gamma$-Tocotrienol; GW-6.4 $\mu$ M GW9662; $\mathrm{T} 0-6.4 \mu \mathrm{M} \mathrm{T} 0070907$

Figure 2: qRT-PCR analysis of treatment of $\gamma$-tocotrienol, GW9662, and T0070907 given alone or in combination on the levels of PPAR $\gamma$ and RXR in (A) MCF-7 and (B) MDA-MB-231 breast cancer cells after a 4-day incubation period. Cells were plated at a density of $2 \times 10^{5}$ cells/well (3 replicates per group) in 6-well plate and treated with control or treatment media for a 4-day culture period. Changes in mRNA levels of PPAR $\gamma$ and RXR were normalized to mRNA level of GAPDH and represented as bar graph. Vertical bars indicate the normalized $C_{t}$ value \pm SEM (Arbitrary Unit) in each treatment group. Luciferase assay to determine PPRE mediated reporter activity in (C) MCF-7 and (D) MDA-MB-231 breast cancer cells after a 4-day incubation period. Cells were plated at a density of $2 \times 10^{4}$ cells/well ( 3 replicates per group) in 96-well plate. Transfections were performed as given in the protocol. Results were calculated as raw luciferase units divided by raw renilla units. Vertical bars indicate PPRE mediated reporter activity \pm SEM (Arbitrary Unit). ${ }^{*} \mathrm{P}<0.05$ as compared with vehicle-treated controls.

levels (Figure 2A and B) and PPRE mediated reporter activity (Figure $\mathbf{2 C}$ and $\mathbf{D}$ ) as compared to the vehicle treated controls. Treatment with $3.2 \mu \mathrm{M}$ GW9662 or T0070907 alone in MCF-7 cells or $6.4 \mu \mathrm{M}$ GW9662 or T0070907 alone in MDA-MB-231 cells had little or no effect on PPAR $\gamma$ or RXR mRNA levels (Figure 2A and B) and PPRE mediated reporter activity (Figure $\mathbf{2 C}$ and D). However, combined treatment with similar doses of $\gamma$-tocotrienol and GW9662 or T0070907 resulted in a relatively significant decrease in PPAR $\gamma$ and $R X R$ mRNA levels (Figure 2A and $\mathbf{B}$ ) and PPRE mediated reporter activity in MCF-7 and MDA-MB-231 breast cancer cell lines as compared to vehicle treated-control cells (Figure 2C and $\mathbf{D}$ ).
3.3. Effects of $\gamma$-Tocotrienol and PPAR $\gamma$ Antagonists (GW9662 and T0070907) Given Alone or in Combination on C/EBPa and C/EBP $\beta$ Levels

Western blot analysis shows that treatment with 2 $\mu \mathrm{M}$ (MCF-7 cells) or $3 \mu \mathrm{M}$ (MDA-MB-231 cells) $\gamma$ tocotrienol and $3.2 \mu \mathrm{M}$ (MCF-7 cells) or $6.4 \mu \mathrm{M}$ (MDAMB-231 cells) of the PPAR $\gamma$ antagonists, GW9662 or T0070907 alone did not induce change in expression of $\mathrm{C} / \mathrm{EBP} \alpha$ and C/EBP $\beta$ as compared to the vehicle treated controls (Figure 3A, B, C, and D). However, combined treatment with these same doses of $\gamma$ tocotrienol and GW9662 or T0070907 caused a significant reduction in levels of C/EBP $\beta$ without any 
MCF-7

A)
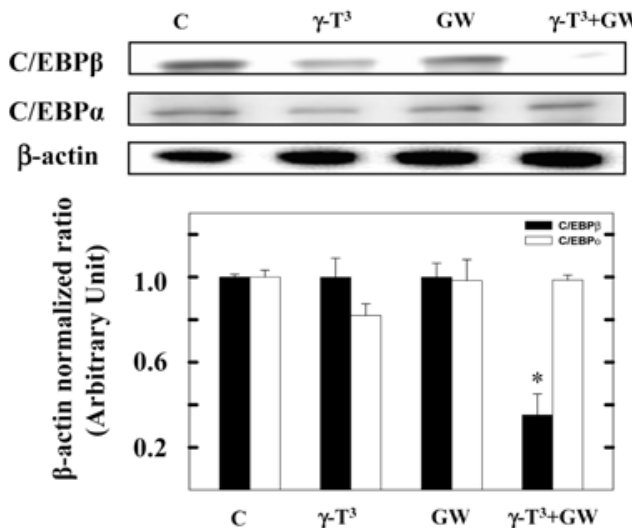

C)
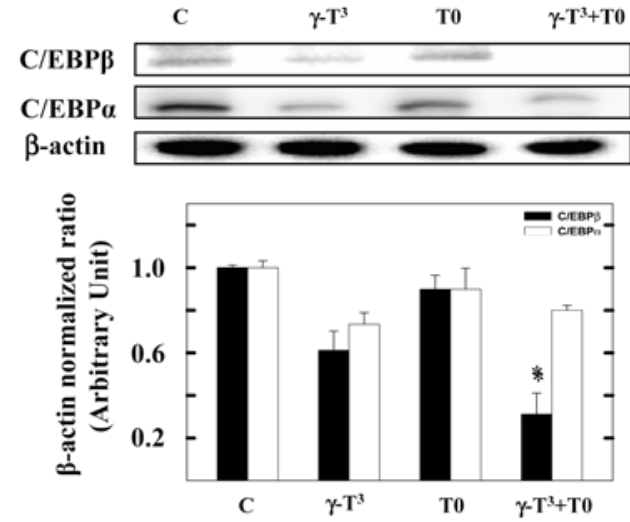

C-Control; $\gamma$-T T $^{3}-2 \mu \mathrm{M} \gamma$-tocotrienol; GW- 3.2 $\mu$ M GW9662; T0- 3.2 $\mu \mathrm{M}$ T0070907
MDA-MB-231

B)

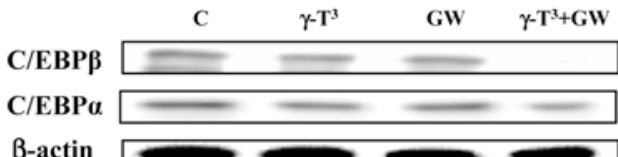

$\beta$-actin

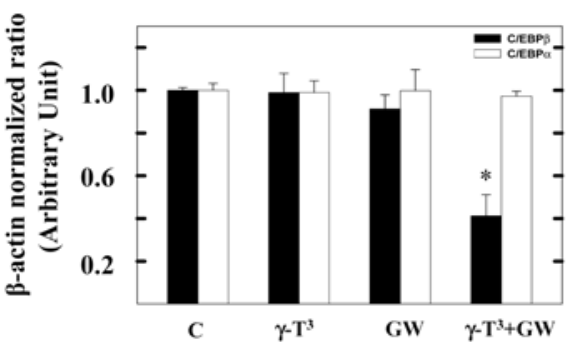

D)
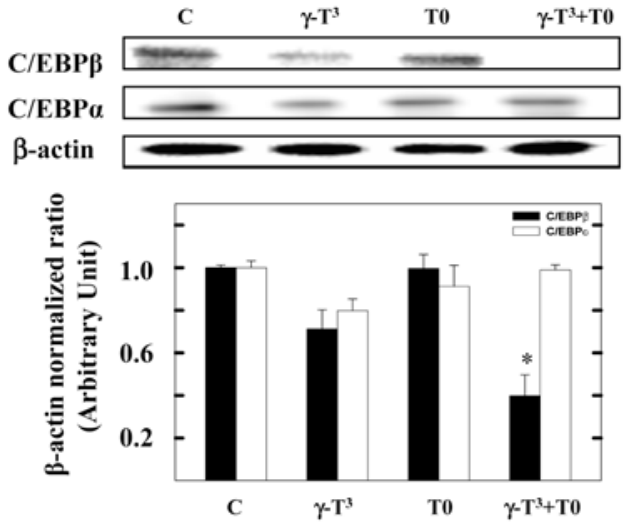

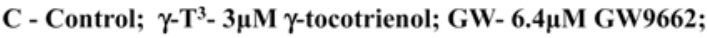

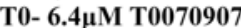

Figure 3: Western blot analysis of treatment of $\gamma$-tocotrienol, GW9662, and T0070907 given alone or in combination on the levels of C/EBPa and C/EBP $\beta$ after a 4-day incubation period in (A and C) MCF-7 and (B and D) MDA-MB-231 breast cancer cells. Cells were plated at $1 \times 10^{6}$ cells $/ 100 \mathrm{~mm}$ culture dish and treated with control or treatment media for 4-day incubation period. Afterwards, whole cell lysates were prepared from each treatment group for subsequent separation by polyacrylamide gel electrophoresis $(50 \mu \mathrm{g} / \mathrm{lane})$ followed by Western blot analysis. Scanning densitometric analysis was performed on all the blots done in triplicate and the integrated optical density of each bond was normalized with corresponding $\beta$-actin, as shown in bar graphs below their respective Western blot images. Vertical bars in the graphs indicate the normalized integrated optical density of bands visualized in each lane \pm SEM (Arbitrary Unit). ${ }^{*} \mathrm{P}<0.05$ as compared with vehicle-treated controls.

change in the expression of C/EBPa in both MCF-7 and MDA-MB-231 cells as compared to vehicle-treated controls (Figure 3A, B, C, and D).

\subsection{Effects of $\gamma$-Tocotrienol and PPAR $\gamma$ Antagonist GW9662 and T0070907 Given Alone or in Combina- tion on SREBP-1c, SREBP 2, and Lipin 1 Levels}

Western blot analysis shows that treatment with 2 $\mu \mathrm{M}$ (MCF-7 cells) or $3 \mu \mathrm{M}$ (MDA-MB-231 cells) $\gamma$ tocotrienol and $3.2 \mu \mathrm{M}$ (MCF-7 cells) or $6.4 \mu \mathrm{M}$ (MDAMB-231 cells) of the PPAR $\gamma$ antagonists, GW9662 or T0070907 alone did not induce change in the expression of SREBP-1c, SREBP 2 and lipin 1 as compared to the vehicle treated controls (Figure 4A, B,
C, and D). However, combined treatment with these same doses of $\gamma$-tocotrienol and GW9662 or T0070907 caused a significant reduction in levels of SREBP-1c and lipin 1 without change in the expression of SREBP 2 in both MCF-7 and MDA-MB-231 cells as compared to vehicle-treated controls (Figure 4A, B, C, and D).

\subsection{Effects of $\gamma$-Tocotrienol and PPAR $\gamma$ Antagonist GW9662 and T0070907 Given Alone or in Combina- tion on mRNA Levels of C/EBP $\beta$ and SREBP-1c}

qRT-PCR analysis shows that treatment with $2 \mu \mathrm{M}$ (MCF-7 cells) or $3 \mu \mathrm{M}$ (MDA-MB-231 cells) $\gamma$ tocotrienol and $3.2 \mu \mathrm{M}$ (MCF-7 cells) or $6.4 \mu \mathrm{M}$ (MDA- 
MCF-7

A)

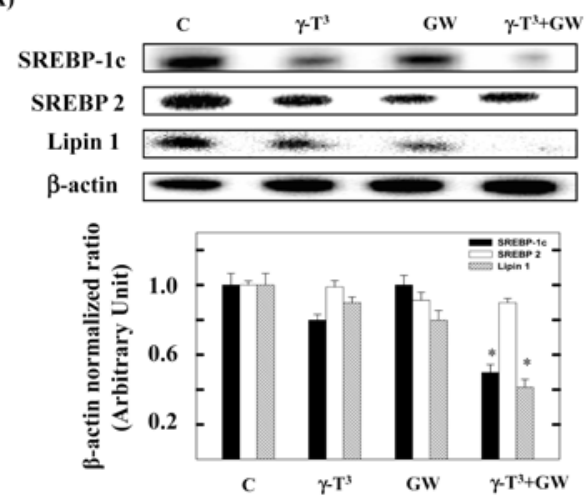

C)
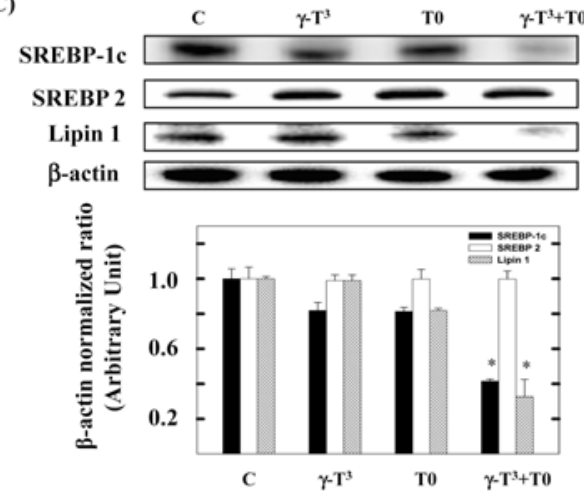

C- Control; $\gamma$-T ${ }^{3}-2 \mu \mathrm{M} \gamma$-tocotrienol; GW- $3.2 \mu \mathrm{M}$ GW9662 T0- $3.2 \mu \mathrm{M} \mathrm{T} 0070907$
B)

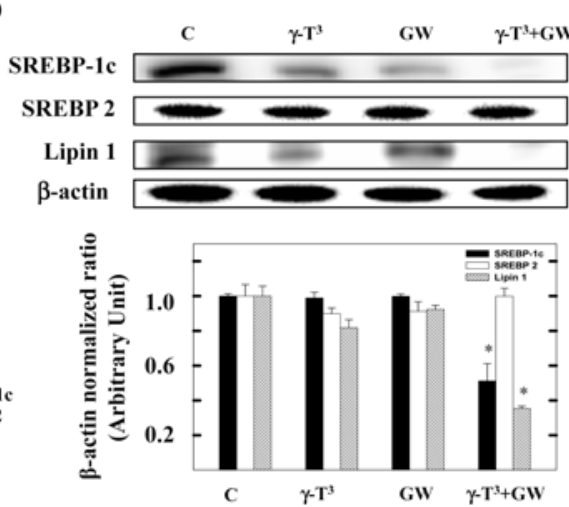

D)
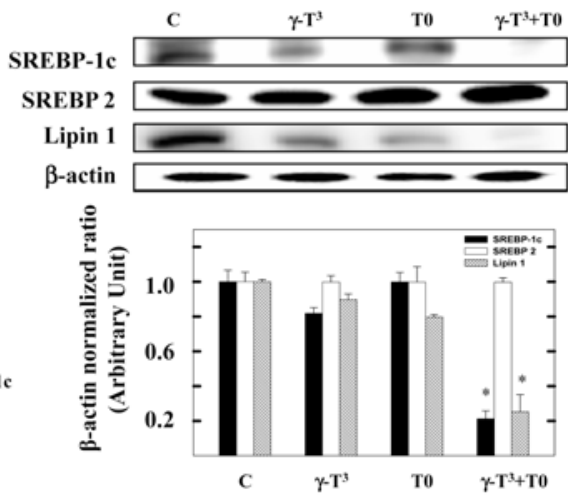

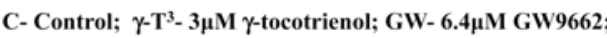

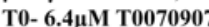

Figure 4: Western blot analysis of treatment of $\gamma$-tocotrienol, GW9662, and T0070907 given alone or in combination on the levels of SREBP-1C, SREBP 2 and Lipin 1 after a 4-day incubation period in (A and C) MCF-7 and (B and D) MDA-MB-231 breast cancer cells. Cells were plated at $1 \times 10^{6}$ cells $/ 100 \mathrm{~mm}$ culture dish and treated with control or treatment media for 4-day incubation period. Afterwards, whole cell lysates were prepared from each treatment group for subsequent separation by polyacrylamide gel electrophoresis $(50 \mu \mathrm{g} / \mathrm{lane})$ followed by Western blot analysis. Scanning densitometric analysis was performed on all the blots done in triplicate and the integrated optical density of each bond was normalized with corresponding $\beta$ actin, as shown in bar graphs below their respective Western blot images. Vertical bars in the graphs indicate the normalized integrated optical density of bands visualized in each lane \pm SEM (Arbitrary Unit). ${ }^{*} P<0.05$ as compared with vehicle-treated controls.

MCF-7

A)

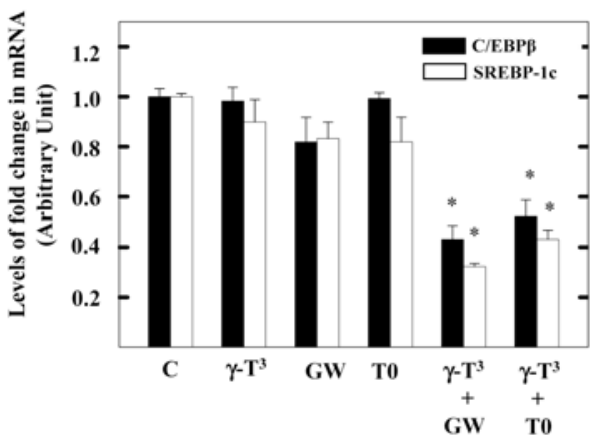

C- Control; $\gamma$-T ${ }^{3}-2 \mu \mathrm{M} \gamma$-tocotrienol; GW-3.2 $\mu \mathrm{M}$ GW9662; T0- 3.2 $\mathrm{M}$ T0070907
MDA-MB-231

B)

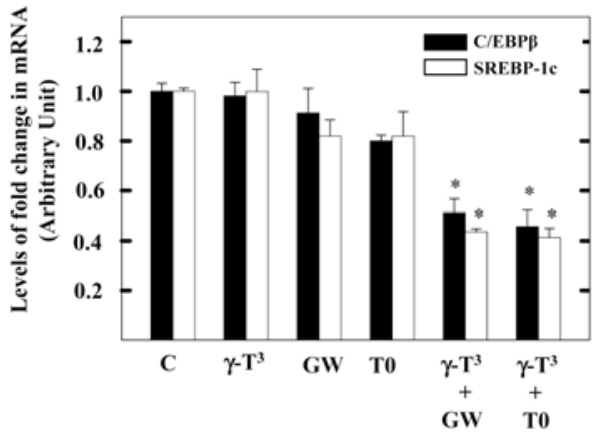

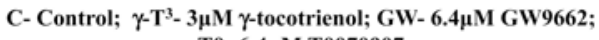
T0- 6.4 $\mu$ M T0070907

Figure 5: qRT-PCR analysis of treatment of $\gamma$-tocotrienol, GW9662, and T0070907 given alone or in combination on the levels of C/EBP $\beta$ and SREBP-1C in (A) MCF-7 and (B) MDA-MB-231 breast cancer cells after a 4-day incubation period. Changes in mRNA levels of C/EBP $\beta$ and SREBP-1c were normalized to mRNA level of GAPDH and represented as bar graph. Vertical bars indicate the normalized $C_{t}$ value \pm SEM (Arbitrary Unit) in each treatment group. ${ }^{*} \mathrm{P}<0.05$ as compared with vehicle-treated controls. 
MB-231 cells) of the PPAR $\gamma$ antagonists, GW9662 or T0070907 alone did not induce any change in the mRNA levels of C/EBP $\beta$ and SREBP-1c (Figure 5A and $\mathbf{B}$ ). However, combined treatment with these same doses of $\gamma$-tocotrienol and GW9662 or T0070907 caused a significant reduction in mRNA levels of C/EBP $\beta$ and SREBP-1C in both MCF-7 and MDA-MB231 cells as compared to vehicle-treated controls (Figure 5A and $\mathbf{B}$ ).

\subsection{Effects of $\gamma$-Tocotrienol and PPAR $\gamma$ Antagonist GW9662 and T0070907 Given Alone or in Combination on FAS, ap2, and HMGCoR Levels}

Western blot analysis shows that treatment with 2 $\mu \mathrm{M}$ (MCF-7 cells) or $3 \mu \mathrm{M}$ (MDA-MB-231 cells) $\gamma$ tocotrienol and $3.2 \mu \mathrm{M}$ (MCF-7 cells) or $6.4 \mu \mathrm{M}$ (MDAMB-231 cells) of the PPAR $\gamma$ antagonists, GW9662 or

A)

\section{MCF-7}
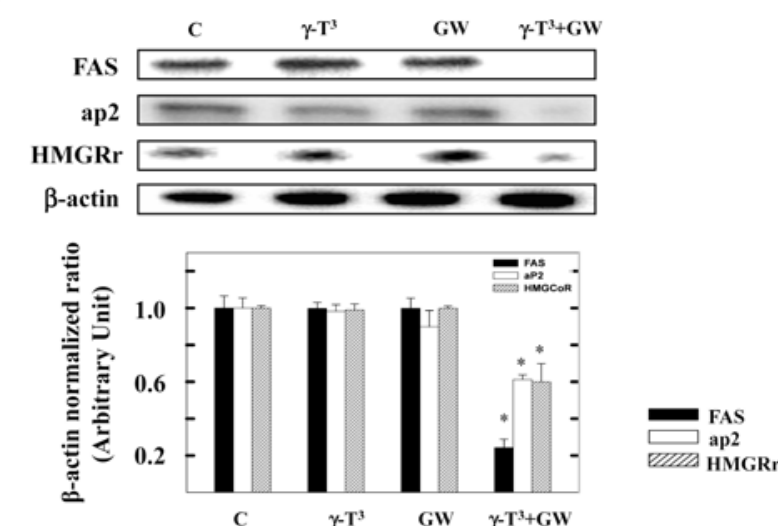

C)
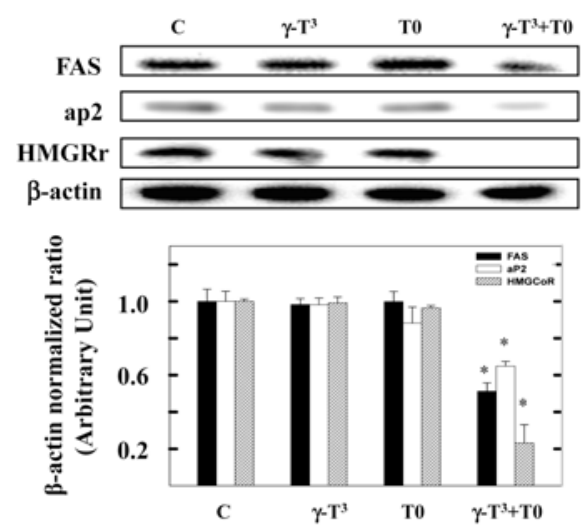

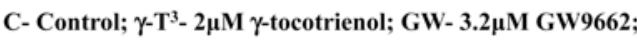

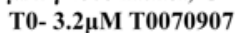

T0070907 alone did not induce any change in expression of FAS, ap2 and HMGCoR as compared to the vehicle-treated controls (Figure 6A, B, C, and D). However, combined treatment with these same doses of $\gamma$-tocotrienol and GW9662 or T0070907 caused a significant reduction in levels of FAS, ap2, and HMGCoR in both MCF-7 and MDA-MB-231 cells as compared to vehicle-treated controls (Figure 6A, B, C, and D).

3.7. Effects of $\gamma$-Tocotrienol and PPAR $\gamma$ Antagonist GW9662 and T0070907 Given Alone or in Combination on Levels of C/EBP $\beta$ and SREBP-1C in PPAR $\gamma$ siRNA Transfected PPAR $\gamma$ Positive MCF-7 and MDA-MB-231 Breast Cancer Cells

PPAR $\gamma$ positive MCF-7 and MDA-MB-231 breast cancer cells were transfected with PPAR $\gamma$ siRNA.

B)
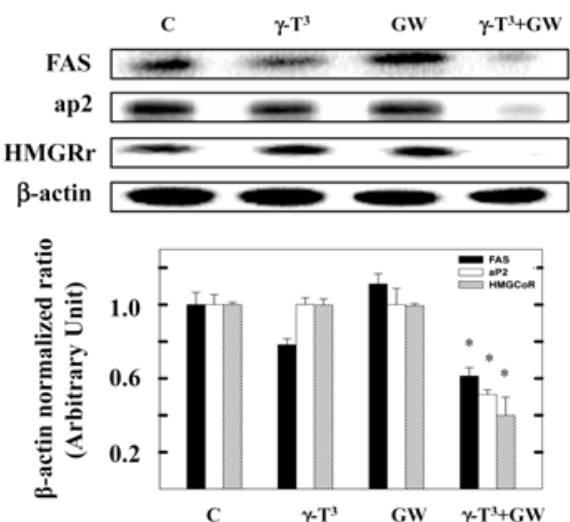

D)

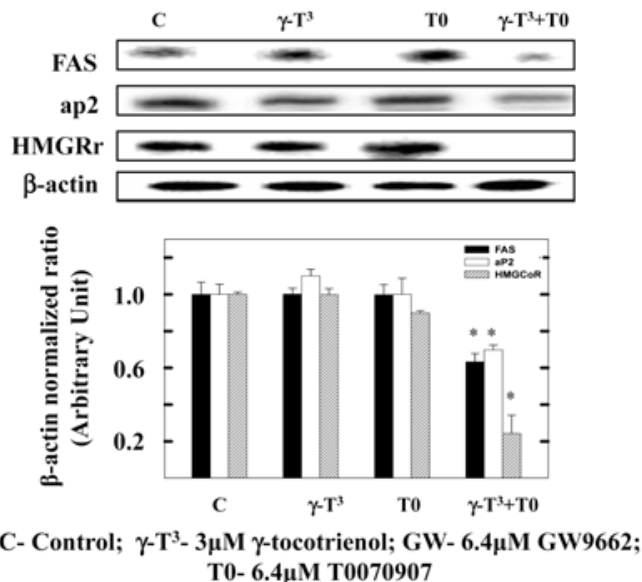

Figure 6: Western blot analysis of treatment of $\gamma$-tocotrienol, GW9662, and T0070907 given alone or in combination on the levels of FAS, ap2 and HMGCoR after a 4-day incubation period in (A and C) MCF-7 and (B and D) MDA-MB-231 breast cancer cells. Cells were plated at $1 \times 10^{6}$ cells $/ 100 \mathrm{~mm}$ culture dish and treated with control or treatment media for 4-day incubation period. Afterwards, whole 6 cell lysates were prepared from each treatment group for subsequent separation by polyacrylamide gel electrophoresis $(50 \mu \mathrm{g} / \mathrm{lane})$ followed by Western blot analysis. Scanning densitometric analysis was performed on all the blots done in triplicate and the integrated optical density of each bond was normalized with corresponding $\beta$-actin, as shown in bar graphs below their respective Western blot images. Vertical bars in the graphs indicate the normalized integrated optical density of bands visualized in each lane \pm SEM (Arbitrary Unit). ${ }^{*} \mathrm{P}<0.05$ as compared with vehicle-treated controls. 
A)
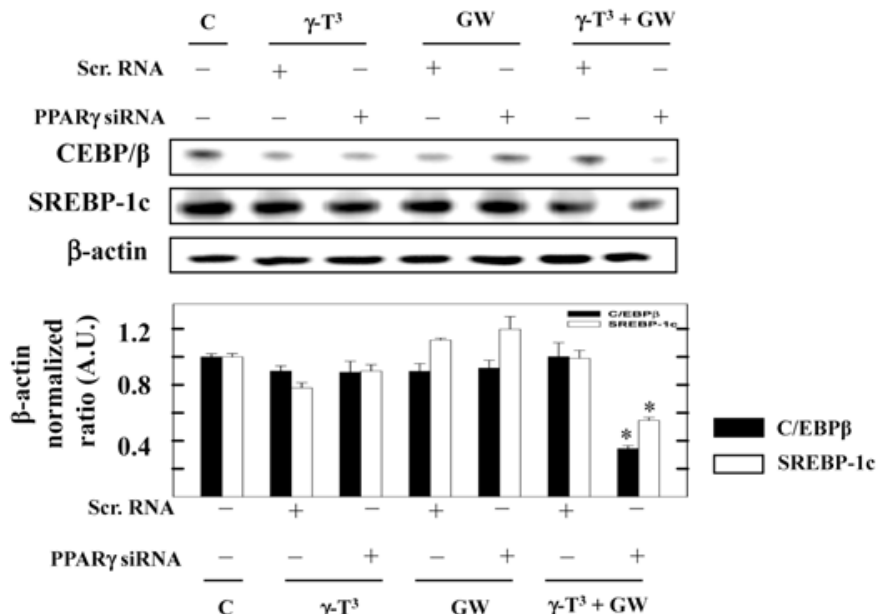

C)
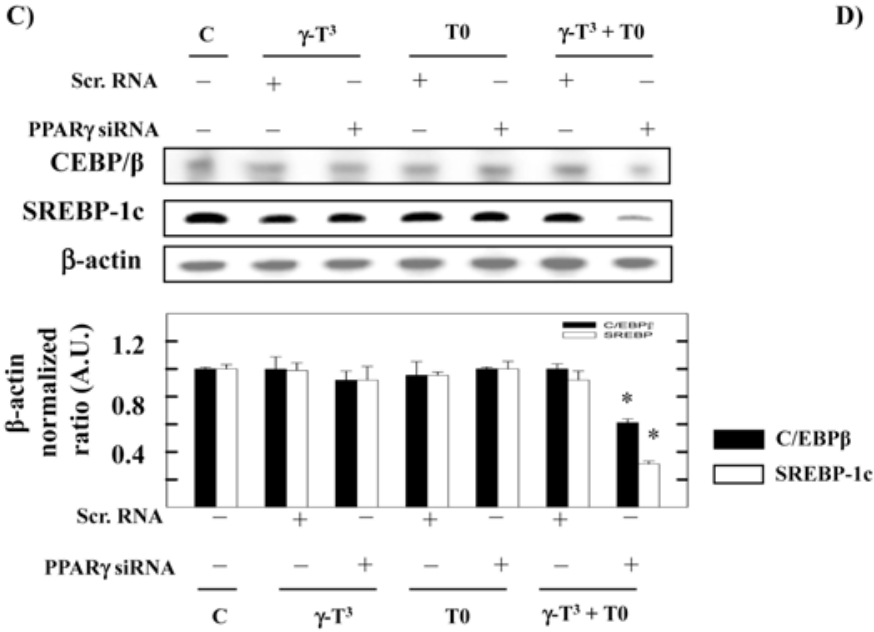

A.U.- Arbitrary Unit; Scr. RNA- Scrambled RNA; C- Control;

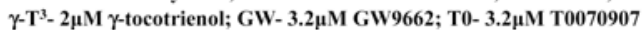

B)
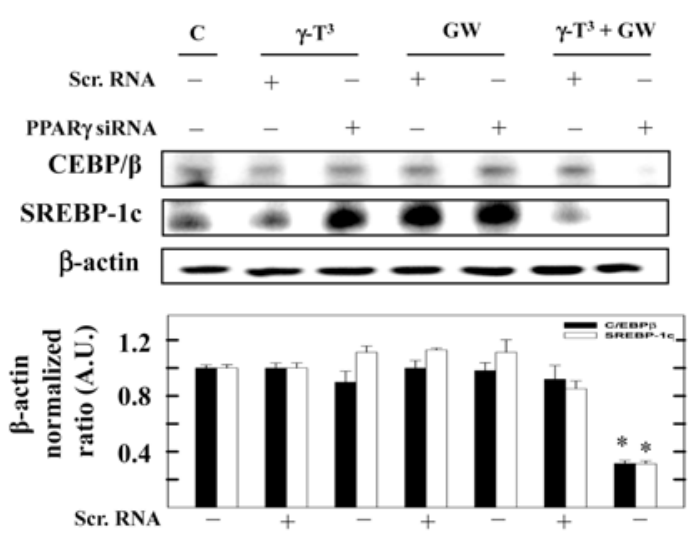

PPAR $\gamma$ siRNA $\frac{-}{\mathrm{C}} \frac{-}{\gamma-\mathrm{T}^{3}} \frac{-}{\mathbf{G W}} \frac{-}{\gamma-\mathrm{T}^{3}+\mathbf{G W}}$

D)
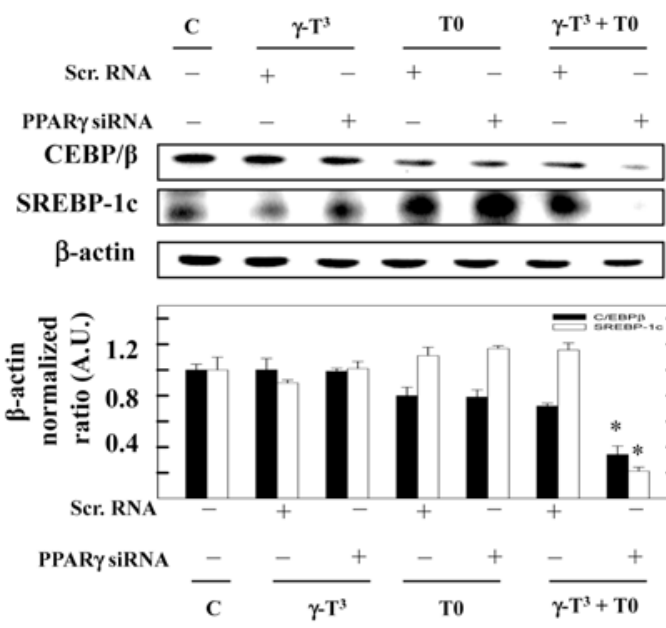

A.U.- Arbitrary Unit; Ser. RNA- Scrambled RNA; C- Control;

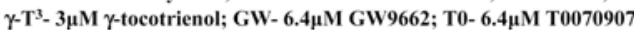

Figure 7: Western blot analysis of treatment effects on levels of C/EBP $\beta$ and SREBP-1C in PPAR $\gamma$ siRNA transfected (A and C) MCF-7 and (B and D) MDA-MB-231 cells. Cells were plated at a density of $2 \times 10^{5}$ cells/well (3 replicates per group) in 6 -well plate in $2 \mathrm{ml}$ antibiotic free media. Transfections were performed using $5 \mu \mathrm{L}$ lipofectamine 2000 according to the manufacturer's protocol. Cells were then exposed to control or treatment media for a 4-day culture period. Afterwards whole cell lysates were prepared from each treatment group for subsequent separation by polyacrylamide gel electrophoresis $(50 \mu \mathrm{g} / \mathrm{lane})$ followed by Western blot analysis. Scanning densitometric analysis was performed on all the blots done in triplicate and the integrated optical density of each bond was normalized with corresponding $\beta$-actin, as shown in bar graphs below their respective Western blot images. Vertical bars in the graphs indicate the normalized integrated optical density of bands visualized in each lane \pm SEM (Arbitrary Unit). ${ }^{*} \mathrm{P}<0.05$ as compared with vehicle-treated controls.

Western blot analysis showed that treatment with $2 \mu \mathrm{M}$ $\gamma$-tocotrienol (MCF-7) or $3 \mu \mathrm{M}$ (MDA-MB-231 cells) $\gamma$ tocotrienol and $3.2 \mu \mathrm{M}$ (MCF-7 cells) or $6.4 \mu \mathrm{M}$ (MDAMB-231 cells) of the PPAR $\gamma$ antagonists, GW9662 or T0070907 alone did not induce any change in the expression of C/EBP $\beta$ and SREBP-1C in comparison to vehicle treated controls or cells transfected with scrambled RNA (Figure 7A, B, C, and D). However, combined treatment with these same doses of $\gamma$ tocotrienol and GW9662 or T0070907 caused a reduction in levels of effects in the expression of C/EBP $\beta$ and SREBP-1C as compared to vehicle treated controls or cells transfected with scrambled RNA in
PPAR $\gamma$ positive MCF-7 and MDA-MB-231 breast cancer cells (Figure 7A, B, C, and D).

\section{DISCUSSION}

Previous studies showed that combined treatment of $\gamma$-tocotrienol with PPAR $\gamma$ antagonists (GW9662 and T0070907) resulted in a synergistic inhibition of MCF-7 and MDA-MB-231 breast cancer cell growth that was mediated by a direct decrease in PPAR $\gamma$ activity and expression [4]. Results in the present study extend these previous findings by demonstrating that combination treatment effects induced by $\gamma$-tocotrienol and PPAR $\gamma$ antagonists is associated with a 
corresponding reduction in adipogenic transcription factors in these human breast cancer cells. Western blot and qRT-PCR studies show that combination treatment resulted in a large reduction in adipogenic protein expression, particularly C/EBP $\beta$, SREBP-1C, ap2, FAS, and HMGCoR. Additional studies showed that combination treatment induced inhibition of C/EBP $\beta$ and SREBP-1C was still observed in MCF-7 and MDA-MB-231 cells transfected with PPAR $\gamma$ siRNA, indicating that treatment effects occur independently of PPAR $\gamma$ expression and activity. These results demonstrate that combined treatment of $\gamma$-tocotrienol with PPAR $\gamma$ antagonists decreased levels of C/EBP $\beta$, SREBP-1c and their target lipogenic enzymes (ap2, FAS, and HMGCoR) in highly proliferating breast cancer cells. These findings suggest that similar combination therapies may provide an important strategy in the treatment of breast cancer.

There is compelling evidence indicating the important role of PPAR family members in lipid sensing and utilization and to aid in cellular protection against lipid excess. Particularly, PPAR $\gamma$ plays a role in fatty acid uptake and transport (e.g. by adipocytes), and acts to control inflammation that can arise from increased adipocyte differentiation and proliferation [30, 31]. However, cancer cells characteristically display high levels of lipids and lipid precursors together with increased levels of PPAR $\gamma$ [32]. It has been hypothesized that PPAR $\gamma$ may act to promote the growth and survival of these highly proliferating malignant cell populations [32]. Numerous investigations have established that $\gamma$-tocotrienol is a potent anticancer agent that inhibits the growth of mouse [3, 33] and human [34, 35] breast cancer cells. In addition, $\gamma$-tocotrienol has been shown to inhibit adipogenesis in 3T3-L1 preadipocytes by suppressing insulin-induced Akt phosphorylation [24]. Studies have also shown that combined treatment of $\gamma$-tocotrienol with other traditional chemotherapies results in synergistic or additive antiproliferative effects against various types of cancer cells [3,33]. Results in the present study further emphasize the importance of down-regulation of PPAR $\gamma$ in cancer cells as a potential therapeutic strategy $[1,8,36]$.

PPAR $\gamma$ regulates adipogenesis with the help of C/EBP family of proteins [37]. Studies conducted on mammary tumor samples show that increased expression of PPAR $\gamma$ results in a corresponding increase in C/EBP $\beta$, and subsequent increase in cancer cell proliferation [38]. In contrast, other studies showed that $\mathrm{C} / \mathrm{EBPa}$ was not involved in cancer progression [17]. Additional reports have shown that PPAR $\gamma$ regulates the SREBP family of transcription factors that are associated with adipocyte differentiation, cholesterol synthesis, and lipid metabolism [39, 40]. PPAR $\gamma$ induces ectopic expression of AAD/SREBP-1C and a related transcription factor SREBP 2 in 3T3L1 cells and HepG2 cells [41]. SREBP-1c and SREBP 2 in turn regulate lipid metabolism by activating FASN [42]. Studies show that there is an increased expression of SREBP-1C and FASN mRNA levels, while SREBP-2 showed less variation in MCF-7 breast cancer cells [18]. Furthermore, targeting SREBP-1c and FASN has recently been recommended as a treatment against breast cancer [43]. PPAR $\gamma$ regulates nuclear translocation of SREBP-1c by controlling lipin 1, a phosphatidic acid phosphatase in 3T3-L1 adipocytes [44]. Lipin 1 is also associated with insulin sensitivity and glucose metabolism in human samples [45]. The decreased level of lipin 1 in the present study suggests that combination treatment may also have a potential role in decreasing glucose metabolism in breast cancer cells. Additional experiments are needed to confirm this hypothesis.

A study conducted by Sim et al., showed that PPAR $\gamma$ antagonist, GW9662 decreased levels of SREBP and HMGCoR to inhibit cholesterol synthesis in human glial progenitor cells. This study suggests the potential role of PPAR $\gamma$ antagonists in inhibiting cholesterol synthesis [46]. HMGCoR is the rate-limiting enzyme in mevalonate pathway for cholesterol synthesis [47]. Interestingly, the mevalonate pathway is constitutively active in malignant cells due to elevated and unregulated HMGCoR activity [23]. Tocotrienols appear to reduce HMGCoR activity by triggering both the retention of SREBP-1c on the endoplasmic reticulum and the degradation of HMGCoR, thereby inducing the reduction in both mRNA and protein HMGCoR levels [25, 48, 49]. Furthermore, combined treatment with subeffective doses of $\gamma$-tocotrienol and various statins (HMGCoR inhibitors) was found to significantly inhibit +SA mammary tumor cell growth associated with a large reduction in HMGCoR expression [23].

PPAR $\gamma$ induced expression of C/EBP $\beta$ is associated with an increase in adipogenesis and synthesis of adipocyte-selective ap2 (fatty acid binding protein) [50]. This adipocyte-selective protein strikes a balance between availability of metabolic resources and the control of inflammatory responses. Studies have shown that these proteins are heavily and aberrantly 
expressed in tumors where they appear to regulate growth and survival responses. Therefore, ap2 offers targeting opportunities for the development of therapeutic treatment for not only cancer, but also other metabolic diseases [51]. Apart from its role as an adipogenic protein, some studies suggest that ap2 may also be involved in breast cancer cell invasion and metastasis, and suggest that ap2 might be used as a diagnostic marker for breast cancer [52]. Other studies have shown that anticancer effects induced by PPAR $\gamma$ antagonists are mediated, in part, by PPAR $\gamma$ independent mechanisms $[53,54]$. These findings are further supported by results in the present study demonstrating that PPAR $\gamma$ ligands mediate adipogenesis through PPAR $\gamma$-independent mechanisms.

In summary, results in the present study show that combined treatment of $\gamma$-tocotrienol with PPAR $\gamma$ antagonists suppress adipogenic proteins and their target genes C/EBP $\beta$, SREBP-1c, ap2, FAS, and HMGCoR. Furthermore, these combination treatment induced effects were found to occur independently of PPAR $\gamma$ expression and activity. Taken together, these findings demonstrate the potential importance of combined treatment of $\gamma$-tocotrienol with PPAR $\gamma$ antagonists as a therapeutic strategy in treatment of breast cancer.

\section{CONFLICT OF INTEREST}

The authors declare that they have no personal financial or competing interests. First Tech International Ltd. provided a grant and purified $\gamma$-tocotrienol that was used in part to support this research.

\section{ACKNOWLEDGEMENTS}

This work was supported in part by Grants from First Tech International Ltd. (Hong Kong), the Malaysian Palm Oil Council (MPOC), and the Louisiana Cancer Foundation. The authors would like to thank the First Tech International Ltd. for generously providing $\gamma$ tocotrienol for use in the studies.

\section{ABBREVIATIONS}

$$
\begin{array}{ll}
\text { Akt } & =\text { Protein kinase } \mathrm{B} \\
\mathrm{BSA} & =\text { Bovine serum albumin } \\
\mathrm{CEBP} & =\text { CCAAT enhancer binding protein } \\
\text { DMEM } & =\text { Dulbecco's modified eagle medium } \\
\text { DMSO } & =\text { Dimethyl sulfoxide }
\end{array}
$$

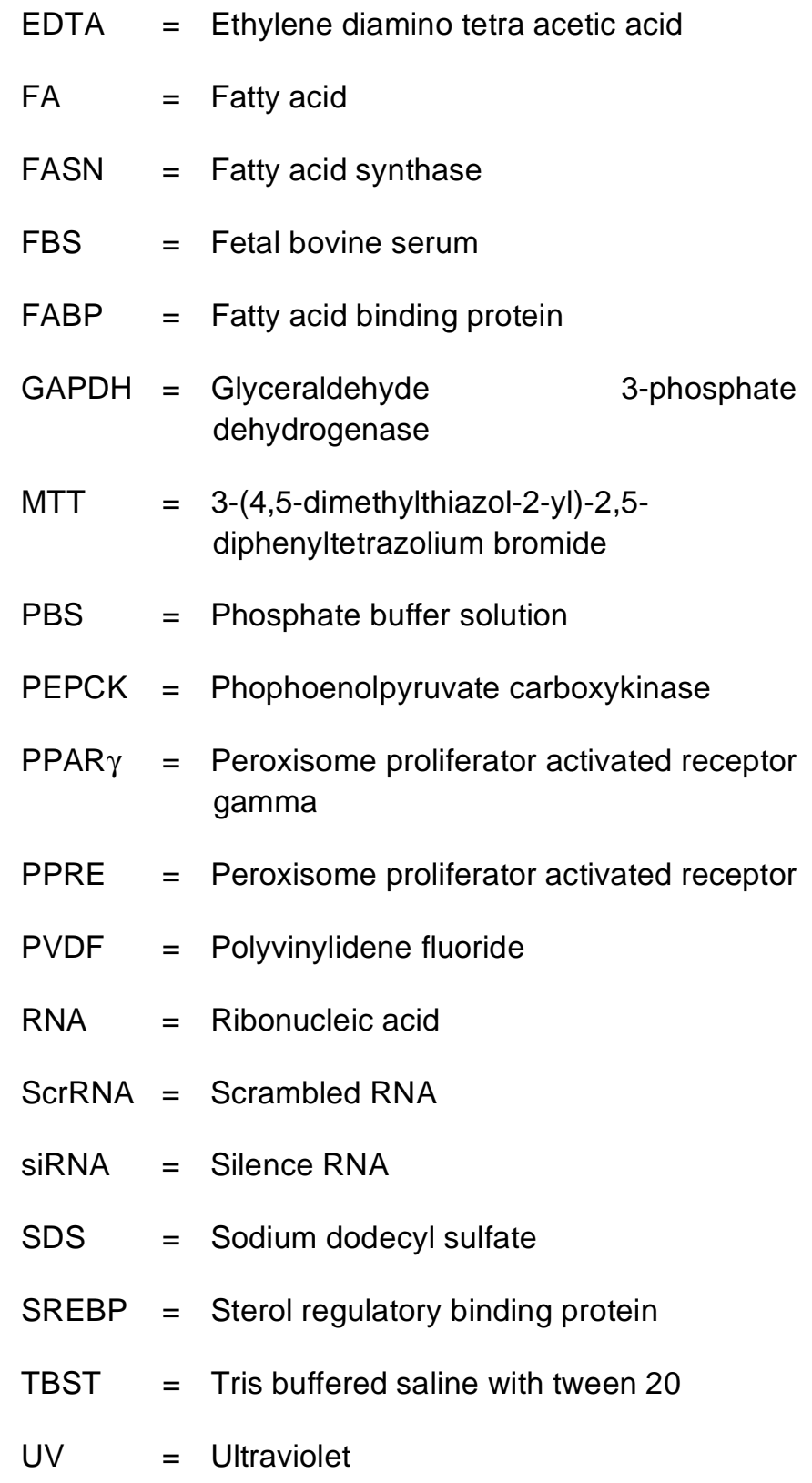

\section{REFERENCES}

[1] Zaytseva YY, Wang X, Southard RC, Wallis NK, Kilgore MW. Down-regulation of PPARgamma1 suppresses cell growth and induces apoptosis in MCF-7 breast cancer cells. Mol Cancer 2008; 7: 90.

http://dx.doi.org/10.1186/1476-4598-7-90

[2] Robbins GT, Nie D. PPAR gamma, bioactive lipids, and cancer progression. Front Biosci 2012; 17: 1816-34. http://dx.doi.org/10.2741/4021

[3] Sylvester PW, Shah SJ. Mechanisms mediating the antiproliferative and apoptotic effects of vitamin $E$ in mammary cancer cells. Front Biosci 2005; 10: 699-709. http://dx.doi.org/10.2741/1565

[4] Malaviya A, Sylvester PW. Mechanisms Mediating the Effects of gamma-Tocotrienol When Used in Combination with PPARgamma Agonists or Antagonists on MCF-7 and MDA-MB-231 Breast Cancer Cells. Int J Breast Cancer 2013; 2013: 101705. http://dx.doi.org/10.1155/2013/101705 
[5] Park J, Euhus DM, Scherer PE. Paracrine and endocrine effects of adipose tissue on cancer development and progression. Endocrine Rev 2011; 32(4): 550-70. http://dx.doi.org/10.1210/er.2010-0030

[6] Nunn AV, Bell J, Barter P. The integration of lipid-sensing and anti-inflammatory effects: how the PPARs play a role in metabolic balance. Nuclear Receptor 2007; 5(1): 1. http://dx.doi.org/10.1186/1478-1336-5-1

[7] Cui Y, Miyoshi K, Claudio E, Siebenlist UK, Gonzalez FJ, Flaws J, et al. Loss of the peroxisome proliferation-activated receptor gamma (PPARgamma) does not affect mammary development and propensity for tumor formation but leads to reduced fertility. J Biol Chem 2002; 277(20): 17830-5. http://dx.doi.org/10.1074/jbc.M200186200

[8] Saez E, Rosenfeld J, Livolsi A, Olson P, Lombardo E, Nelson $\mathrm{M}$, et al. PPAR gamma signaling exacerbates mammary gland tumor development. Genes Dev 2004; 18(5): 528-40. http://dx.doi.org/10.1101/gad.1167804

[9] Edwards IJ, O'Flaherty JT. Omega-3 Fatty Acids and PPARgamma in Cancer. PPAR Res 2008; 2008: 358052. http://dx.doi.org/10.1155/2008/358052

[10] Koh YK, Lee MY, Kim JW, Kim M, Moon JS, Lee YJ, et al. Lipin1 is a key factor for the maturation and maintenance of adipocytes in the regulatory network with CCAAT/enhancerbinding protein alpha and peroxisome proliferator-activated receptor gamma 2. J Biol Chem 2008; 283(50): 34896-906. http://dx.doi.org/10.1074/jbc.M804007200

[11] Peterson TR, Sengupta SS, Harris TE, Carmack AE, Kang $\mathrm{SA}$, Balderas $\mathrm{E}$, et al. mTOR complex 1 regulates lipin 1 localization to control the SREBP pathway. Cell 2011; 146(3): 408-20. http://dx.doi.org/10.1016/j.cell.2011.06.034

[12] Rosen ED, Spiegelman BM. Molecular regulation of adipogenesis. Ann Rev Cell Develop Biol 2000; 16: 145-71. http://dx.doi.org/10.1146/annurev.cellbio.16.1.145

[13] Tontonoz P, Hu E, Devine J, Beale EG, Spiegelman BM. PPAR gamma 2 regulates adipose expression of the phosphoenolpyruvate carboxykinase gene. Mol Cell Biol 1995; 15(1): 351-7. http://www.ncbi.nlm.nih.gov/pubmed/ 7799943

[14] Chatterjee S, Szustakowski JD, Nanguneri NR, Mickanin C, Labow MA, Nohturfft A, et al. Identification of novel genes and pathways regulating SREBP transcriptional activity. PloS One 2009; 4(4): e5197. http://dx.doi.org/10.1371/journal.pone.0005197

[15] Klopotek A, Hirche F, Eder K. PPAR gamma ligand troglitazone lowers cholesterol synthesis in HepG2 and Caco-2 cells via a reduced concentration of nuclear SREBP2. Exp Biol Med (Maywood) 2006; 231(8): 1365-72. http://www.ncbi.nlm.nih.gov/pubmed/16946405

[16] Menendez JA, Lupu R. Fatty acid synthase and the lipogenic phenotype in cancer pathogenesis. Nat Rev Cancer 2007; 7(10): 763-77.

http://dx.doi.org/10.1038/nrc2222

[17] Milde-Langosch K, Loning T, Bamberger AM. Expression of the CCAAT/enhancer-binding proteins C/EBPalpha, C/EBPbeta and C/EBPdelta in breast cancer: correlations with clinicopathologic parameters and cell-cycle regulatory proteins. Breast Cancer Res Treat 2003; 79(2): 175-85. http://dx.doi.org/10.1023/A:1023929504884

[18] Yang Y, Morin PJ, Han WF, Chen T, Bornman DM, Gabrielson EW, Pizer ES. Regulation of fatty acid synthase expression in breast cancer by sterol regulatory element binding protein-1c. Exp Cell Res 2003; 282(2): 132-7. http://dx.doi.org/10.1016/S0014-4827(02)00023-X

[19] Mclntyre BS, Briski KP, Gapor A, Sylvester PW. Antiproliferative and apoptotic effects of tocopherols and tocotrienols on preneoplastic and neoplastic mouse mammary epithelial cells. Proc Soc Exp Biol Med 2000a; 224(4): 292-301.

http://dx.doi.org/10.1046/j.1525-1373.2000.22434.x
[20] Mclntyre BS, Briski KP, Tirmenstein MA, Fariss MW, Gapor A, Sylvester PW. Antiproliferative and apoptotic effects of tocopherols and tocotrienols on normal mouse mammary epithelial cells. Lipids 2000b; 35(2): 171-80.

http://dx.doi.org/10.1007/BF02664767

[21] Samant GV, Sylvester PW. gamma-Tocotrienol inhibits ErbB3-dependent PI3K/Akt mitogenic signalling in neoplastic mammary epithelial cells. Cell Prolif 2006; 39(6): 563-74. http://dx.doi.org/10.1111/j.1365-2184.2006.00412.x

[22] Shah S, Sylvester PW. Tocotrienol-induced caspase-8 activation is unrelated to death receptor apoptotic signaling in neoplastic mammary epithelial cells. Exp Biol Med (Maywood) 2004; 229(8): 745-55. http://www.ncbi.nlm.nih. gov/pubmed/15337828

[23] Wali VB, Sylvester PW. Synergistic antiproliferative effects of gamma-tocotrienol and statin treatment on mammary tumor cells. Lipids 2007; 42(12): 1113-23. http://dx.doi.org/10.1007/s11745-007-3102-0

[24] Uto-Kondo $H$, Ohmori R, Kiyose C, Kishimoto $Y$, Saito $H$, Igarashi $\mathrm{O}$, Kondo $\mathrm{K}$. Tocotrienol suppresses adipocyte differentiation and Akt phosphorylation in 3T3-L1 preadipocytes. J Nutr 2009; 139(1): 51-7. http://dx.doi.org/10.3945/jn.108.096131

[25] Song BL, DeBose-Boyd RA. Insig-dependent ubiquitination and degradation of 3-hydroxy-3-methylglutaryl coenzyme a reductase stimulated by delta- and gamma-tocotrienols. J Biol Chem 2006; 281(35): 25054-61. http://dx.doi.org/10.1074/jbc.M605575200

[26] Fang F, Kang Z, Wong C. Vitamin E tocotrienols improve insulin sensitivity through activating peroxisome proliferatoractivated receptors. Mol Nutr Food Res 2010; 54(3): 345-52. http://dx.doi.org/10.1002/mnfr.200900119

[27] Laemmli UK. Cleavage of structural proteins during the assembly of the head of bacteriophage T4. Nature 1970; 227(259): 680-5.

http://dx.doi.org/10.1038/227680a0

[28] Sylvester PW, Birkenfeld HP, Hosick HL, Briski KP. Fatty acid modulation of epidermal growth factor-induced mouse mammary epithelial cell proliferation in vitro. Exp Cell Res 1994; 214(1): 145-53. http://dx.doi.org/10.1006/excr.1994.1243

[29] Towbin H, Staehelin T, Gordon J. Electrophoretic transfer of proteins from polyacrylamide gels to nitrocellulose sheets: procedure and some applications. Proc Natl Acad Sci USA 1979; 76(9): 4350-4.

http://dx.doi.org/10.1073/pnas.76.9.4350

[30] Armoni M, Harel C, Karnieli E. Transcriptional regulation of the GLUT4 gene: from PPAR-gamma and FOXO1 to FFA and inflammation. Trends in Endocrinology and Metabolism: TEM 2007; 18(3): 100-7. http://www.ncbi.nlm.nih.gov/ pubmed/17317207

[31] Chinetti G, Fruchart JC, Staels B. Peroxisome proliferatoractivated receptors (PPARs): nuclear receptors at the crossroads between lipid metabolism and inflammation. Inflammation research: official journal of the European Histamine Research Society [et al] 2000; 49(10): 497-505. http://www.ncbi.nlm.nih.gov/pubmed/11089900

[32] Garber K. Energy deregulation: licensing tumors to grow. Science 2006; 312(5777): 1158-9. http://dx.doi.org/10.1126/science.312.5777.1158

[33] Sylvester PW. Vitamin E and apoptosis. Vitam Horm 2007; 76: 329-56. http://dx.doi.org/10.1016/S0083-6729(07)76012-0

[34] Nesaretnam K, Guthrie N, Chambers AF, Carroll KK. Effect of tocotrienols on the growth of a human breast cancer cell line in culture. Lipids 1995; 30(12): 1139-43. http://dx.doi.org/10.1007/BF02536615

[35] Nesaretnam K, Stephen R, Dils R, Darbre P. Tocotrienols inhibit the growth of human breast cancer cells irrespective of estrogen receptor status. Lipids 1998; 33(5): 461-9. http://dx.doi.org/10.1007/s11745-998-0229-3 
[36] Mueller E, Sarraf P, Tontonoz P, Evans RM, Martin KJ, Zhang $\mathrm{M}$, et al. Terminal differentiation of human breast cancer through PPAR gamma. Mol Cell 1998; 1(3): 465-70. http://dx.doi.org/10.1016/S1097-2765(00)80047-7

[37] Wu Z, Bucher NL, Farmer SR. Induction of peroxisome proliferator-activated receptor gamma during the conversion of $3 T 3$ fibroblasts into adipocytes is mediated by C/EBPbeta, C/EBPdelta, and glucocorticoids. Mol Cell Biol 1996; 16(8): 4128-36. http://www.ncbi.nlm.nih.gov/pmc/articles/PMC 231409/

[38] Zahnow CA. CCAAT/enhancer binding proteins in normal mammary development and breast cancer. Breast Cancer Research: BCR 2002; 4(3): 113-21. http://dx.doi.org/10.1186/bcr428

[39] Alo PL, Visca P, Marci A, Mangoni A, Botti C, Di Tondo U. Expression of fatty acid synthase (FAS) as a predictor of recurrence in stage I breast carcinoma patients. Cancer 1996; 77(3): 474-82.

http://dx.doi.org/10.1002/(SICl)10970142(19960201)77:3<474::AID-CNCR8>3.0.CO;2-K

[40] DeBose-Boyd RA. Feedback regulation of cholesterol synthesis: sterol-accelerated ubiquitination and degradation of HMG CoA reductase. Cell Res 2008; 18(6): 609-21. http://dx.doi.org/10.1038/cr.2008.61

[41] Fajas L, Schoonjans K, Gelman L, Kim JB, Najib J, Martin G, et al. Regulation of peroxisome proliferator-activated receptor gamma expression by adipocyte differentiation and determination factor $1 /$ sterol regulatory element binding protein 1: implications for adipocyte differentiation and metabolism. Mol Cell Biol 1999; 19(8): 5495-503. http://www.ncbi.nlm.nih.gov/pubmed/10409739

[42] Horton JD, Goldstein JL, Brown MS. SREBPs: activators of the complete program of cholesterol and fatty acid synthesis in the liver. J Clin Investig 2002; 109(9): 1125-31. http://www.ncbi.nlm.nih.gov/pmc/articles/PMC150968/

[43] Kuhajda FP, Jenner K, Wood FD, Hennigar RA, Jacobs LB, Dick JD, Pasternack GR. Fatty acid synthesis: a potential selective target for antineoplastic therapy. Proc Natl Acad Sci USA 1994; 91(14): 6379-83.

http://dx.doi.org/10.1073/pnas.91.14.6379

[44] Finck BN, Gropler MC, Chen Z, Leone TC, Croce MA, Harris $\mathrm{TE}$, et al. Lipin 1 is an inducible amplifier of the hepatic PGC1alpha/PPARalpha regulatory pathway. Cell Metabol 2006; 4(3): 199-10. http://dx.doi.org/10.1016/j.cmet.2006.08.005

[45] Suviolahti E, Reue K, Cantor RM, Phan J, Gentile M, Naukkarinen J, et al. Cross-species analyses implicate Lipin
1 involvement in human glucose metabolism. Human Mol Genet 2006; 15(3): 377-86.

http://dx.doi.org/10.1093/hmg/ddi448

[46] Sim FJ, Lang JK, Ali TA, Roy NS, Vates GE, Pilcher WH, Goldman SA. Statin treatment of adult human glial progenitors induces PPAR gamma-mediated oligodendrocytic differentiation. Glia 2008; 56(9): 954-62. http://dx.doi.org/10.1002/glia.20669

[47] Goldstein JL, Brown MS. Regulation of the mevalonate pathway. Nature 1990; 343(6257): 425-30. http://dx.doi.org/10.1038/343425a0

[48] Mo H, Elson CE. Studies of the isoprenoid-mediated inhibition of mevalonate synthesis applied to cancer chemotherapy and chemoprevention. Exp Biol Med (Maywood) 2004; 229(7): 567-85. http://www.ncbi.nlm.nih. gov/pubmed/15229351

[49] Parker RA, Pearce BC, Clark RW, Gordon DA, Wright JJ. Tocotrienols regulate cholesterol production in mammalian cells by post-transcriptional suppression of 3-hydroxy-3methylglutaryl-coenzyme A reductase. J Biol Chem 1993; 268(15): 11230-8. http://www.ncbi.nlm.nih.gov/pubmed/ 8388388

[50] Wu Z, Xie Y, Bucher NL, Farmer SR. Conditional ectopic expression of $\mathrm{C} / \mathrm{EBP}$ beta in NIH-3T3 cells induces PPAR gamma and stimulates adipogenesis. Genes Dev 1995; 9(19): 2350-63.

http://dx.doi.org/10.1101/gad.9.19.2350

[51] Furuhashi M, Hotamisligil GS. Fatty acid-binding proteins: role in metabolic diseases and potential as drug targets. Nat Rev Drug Discov 2008; 7(6): 489-503. http://dx.doi.org/10.1038/nrd2589

[52] Li H, Lu Q, Dong LH, Xue H, Zhou HY, Yang HJ. [Expression of fatty acid binding protein in human breast cancer tissues]. $\mathrm{Xi}$ bao yu fen zi mian yi xue za zhi $=$ Chinese $\mathrm{J}$ Cell Mol Immunol 2007; 23(4): 312-6. http://www.ncbi.nlm.nih.gov/ pubmed/17428383

[53] Chawla A, Barak Y, Nagy L, Liao D, Tontonoz P, Evans RM. PPAR-gamma dependent and independent effects on macrophage-gene expression in lipid metabolism and inflammation. Nat Med 2001; 7(1): 48-52. http://dx.doi.org/10.1038/83336

[54] Vernochet C, Milstone DS, lehle C, Belmonte N, Phillips B, Wdziekonski B, et al. PPARgamma-dependent and PPARgamma-independent effects on the development of adipose cells from embryonic stem cells. FEBS Lett 2002; 510(1-2): 94-8.

http://dx.doi.org/10.1016/S0014-5793(01)03235-5

Received on 21-12-2013

Accepted on 15-01-2014

Published on 31-01-2014

DOI: http://dx.doi.org/10.6000/1927-5951.2014.04.01.7

(C) 2014 Malaviya et al.; Licensee Lifescience Global.

This is an open access article licensed under the terms of the Creative Commons Attribution Non-Commercial License (http://creativecommons.org/licenses/by-nc/3.0/) which permits unrestricted, non-commercial use, distribution and reproduction in any medium, provided the work is properly cited. 